\title{
'SI DOEL ANAK SEKOLAHAN', SINETRON INDONESIA PALING FENOMENAL (Tinjauan Ilmu Komunikasi atas Sinetron Si Doel Anak Sekolahan)
}

\author{
Aceng Abdullah ${ }^{1}$, Jimi Narotama Mahameruaji ${ }^{2}$, Evi Rosfiantika ${ }^{3}$ \\ ${ }^{1,2,3}$ Program Studi Televisi dan Film, Fakultas Ilmu Komunikasi, \\ Universitas Padjadjaran
}

\begin{abstract}
ABSTRAK
Sinetron "Si Doel Anak Sekolahan" (SDAS) arahan Rano Karno sampai tahun 2018 masih diputar ulang di salah satu stasiun TV kita. "SDAS" saat ini menjadi satu-satunya sinetron yang sukses meraih simpati penonton di Indonesia. Selain mampu meraih rating dan share tertinggi dalam acara televisi di Indonesia pada tahun 90-an, sinetron ini sampai hampir 25 tahun kemudian masih diputar ulang dan masih dipercaya oleh para pemasang iklan. Karena daya tariknya, SDAS pun sukses di beberapa versi layar lebar termasuk "Si Doel The Movie" yang menjadi film nomor-4 di Indonesia yang paling digemari. Mengapa sinetron ini begitu fenomenal, padahal di pertengahan tahun 90-an itu hampir semua stasiun TV sedang terlena dengan sinetron-sinetron yang mengumbar kemewahan dan seting kisah yang tidak realistis, sementara SDAS hanyalah sebuah sinetron berjenre etnis yang pemainnya kebanyakan adalah seniman lenong Betawi dan Srimulat yang berkisah tentang kaum marginal yang terpinggirkan secara sosial, ekonomi termasuk pendidikan. Studi ini bertujuan untuk mengetahui Genre, nilai dramatik serta aspek Komunikasi dalam Sinetron Si Doel Anak Sekolahan Berdasarkan kajian ilmu komunikasi, SDAS sukses karena kisah yang ditampilkan, tokoh yang dimunculkan, setting dan adegan yang dibangun merupakan refleksi dari wajah khalayak televisi Indonesia sendiri. SDAS adalah gambaran masyarakat Indonesia yang sesungguhnya. Keluguan dan kesederhanaan yang ditampilkan tampil dengan natural tidak berlebihan. Dari sudut pandang ilmu komunikasi klasik, SDAS sudah amat sesuai dengan bidang pengalaman dan kerangka referensi dari khalayaknya.
\end{abstract}

Kata-kata Kunci: Indonesia; Si Doel Anak Sekolahan; Sinetron; TV

\section{'SI DOEL ANAK SEKOLAHAN', THE MOST PHENOMENAL INDONESIA'S TV SERIES (Review of Communication Science on Si Doel Anak Sekolahan TV Series)}

\begin{abstract}
The TV series "Si Doel Anak Sekolahan" (SDAS) directed by Rano Karno until 2018 is still playing back on one of our TV stations. "SDAS" is currently the only TV series that has successfully won the sympathy of viewers in Indonesia. In addition to being able to get the highest rating and share in television shows in Indonesia in the 90s, this soap opera until almost 25 years later is still playing back and is still trusted by advertisers. Because of its appeal, SDAS also succeeded in several wide-screen versions including "Si Doel The Movie" which became the 4th most popular film in Indonesia. Why is this TV series so phenomenal, even though in the mid 90's almost all TV stations were complacent with soap operas that indulged luxury and setting unrealistic stories, while SDAS was just an ethnic genre $T V$ series whose players were mostly Betawi and Srimulat artists, which tells about marginal people who are social, economically, and educationally marginalized. This study aims to find out the genre, dramatic values and aspects of communication in the Si Doel Anak Sekolahan TV series. Based on the study of communication science, SDAS is successful because the story presented, the figures that were raised, the settings and scenes that were built were a replica of the faces of Indonesian television audiences themselves. SDAS is a picture of real Indonesian society. The innocence and simplicity shown by nature are not excessive. From the point of view of classical communication, SDAS is very suitable with the field of experience and reference framework of the audience.
\end{abstract}

Keywords: Indonesia; Si Doel Anak Sekolahan; TV Series; TV

Korespondensi: Aceng Abdullah. Program Studi Televisi dan Film, Fakultas Ilmu Komunikasi, Universitas Padjadjaran, Jl. Raya Bandung-Sumedang Km. 21, Sumedang.

Email: aceng.abdullah@unpad.ac.id 


\section{PENDAHULUAN}

Sinetron Si Doel Anak Sekolahan (SDAS), merupakan satu-satunya sinetron Indonesia yang sangat fenomenal. Karya sinematografi ini begitu mengena di hati masyarakat Indonesia sehingga kendati sudah berusia 25 tahun sejak produksi pertamanya di tahun 1994, sinetron ini masih disukai, terbukti SDAS berkali-kali ditayangkan ulang oleh stasiun TV dan penontonnya masih tetap setia, bahkan tidak sedikit generasi yang ketika SDAS mulai diputar masih usia balita, sekarang ikut menyukai SDAS.

Karena sangat disukai, Tahun 2018 ketika dibuat sebagai film layar lebar berjudul "Si Doel The Movie", film ini terbilang sukses di pasaran bahkan menjadi film Indonesia nomer 4 yang paling banyak penontonnya, seperti yang terlihat dalam tabel berikut ini :

Tabel 1 Film Indonesia Dengan Penonton Terbanyak Tahun 2018

\begin{tabular}{|c|l|c|}
\hline NO & \multicolumn{1}{|c|}{ JUDUL FILM } & PENONTON \\
\hline 1 & Dilan 1990 & 6.315 .664 \\
\hline 2 & $\begin{array}{l}\text { Suzzanna: Bernapas } \\
\text { dalam Kubur }\end{array}$ & 3.270 .468 \\
\hline 3 & Danur 2: Maddah & 2.572 .672 \\
\hline 4 & Si Doel the Movie & 1.757 .653 \\
\hline 5 & Asih & 1.714 .798 \\
\hline
\end{tabular}

Sumber: (Ulfa, 2018)

Apa dan bagaimana tentang sinetron ini, serta mengapa sinetron ini begitu digemari padahal settingnya adalah keluarga kampung pinggiran Jakarta, bukan setting keluarga kaya raya dimana di jamannya sinetron yang menampilkan kemewahan selalu menjadi panutan penonton film dan sinetron Indonesia.

Kendati karya film dan televisi dianggap sebagai karya seni, namun Film dan televisi merupakan media komunikasi massa, sehingga konten film dan televisi dapat dikaji dari perspektif ilmu komunikasi. Film dan sinetron yang berhasil meraih simpati penonton dengan jumlah penonton yang besar (rating dan sharenya tinggi) merupakan karya seni yang komunikatif yang pesannya tepat dan mengena bagi khalayaknya.

\section{TINJAUAN PUSTAKA}

\section{Sekilas tentang Sinetron "Si Doel Anak}

\section{Sekolahan"}

Si Doel Anak Sekolahan (SDAS), adalah sinetron arahan sutradara Rano Karno yang diproduksi pertama kali pada tahun 1994. Sinetron ini mengadaptasi karya sinematografi layar lebar atau film bioskop sebelumnya berjudul "Si Doel Anak Betawi" pada tahun 1973 karya sutradara Syumanjaya yang dibintangi juga oleh Rano Karno yang saat itu masih berusia SD. Film ini diangkat dari novel "Si Doel Anak Jakarta" karya Aman Datok Modjoindo.

Rano Karno rupanya begitu terkesan dengan film Si Doel Anak Betawi ini sehingga melalui perusahaan milik keluarganya, Karnos Film, mengadaptasinya menjadi "Si Doel Anak Sekolahan". Dalam sebuah wawancara di sebuah suratkabar, Rano Karno sempat kecewa terhadap sebuah stasiun TV yang awalnya menolak sinetron ini untuk ditayangkan di 
stasiun tersebut karena SDAS dianggap terlalu "kampungan" atau tradisional, sehingga dikhawatirkan tidak akan disukai. SDAS pertama hanya berisi empat episode, di luar dugaan, ternyata empat episode pertama itu respon penonton sangat bagus.

SDAS Dua dan seterusnya pun diproduksi, yang ternyata juga terus disukai sehingga serial ini mencapai 162 episode. SDAS pun memiliki angka share dan rating tertinggi dibanding sinetron lainnya, padahal sinetron ini tidak menjual kemewahan atau keglamouran yang justru saat itu tengah digandrungi dan menjadi trend pada sejumlah sinetron yang tengah diputar di banyak stasiun TV nasional. Karena kemewahan dan keglamouran tadi menjadi trend sinetron Indonesia saat itu, kehadiran SDAS pada awalnya ini ditolak sebuah stasiun TV. SDAS mengangkat tentang kehidupan keluarga Betawi di pinggiran Jakarta yang jauh dari kesan glamour. SDAS tampil apa adanya sehingga pada awalnya banyak yang meramalkan tidak akan sukses karena khalayak sinetron Indonesia hanya menyukai sesuatu yang bersifat wah kendati dia sendiri berasal dari keluarga kalangan bawah.

SDAS mengisahkan tentang pasangan keluarga Bang Sabeni (Benyamin Sueb) dan Amineh (Aminah Cendrakasih), yang memiliki dua anak, Kasdoelah alias Doel (Rano Karno) dan Atun (Suti Karno). Ikut tinggal serumah dari keluarga itu Bang Mandra (Mandra). Mandra dikisahkan sebagai adik kandung Nyak Amineh. Mandra berprofesi sebagai kondektur oplet milik Bang Sabeni. Sekali-kali Mandra juga menjadi sopir.

Si Doel adalah mahasiswa Fakultas Teknik sebuah PTS. Di kampusnya dia didekati oleh seorang mahasiswi Jurusan Antropologi bernama Sarah (Cornelia Agatha) yang tengah melakukan riset tentang keluarga Betawi untuk skripsinya. Sarah dikenalkan ke Doel oleh sepupunya bernama Hans yang satu fakultas dengan Si Doel. Rupanya Sarah bukan sekedar meneliti tentang keluarga Betawi, tetapi jatuh hati kepada Doel, sementara Doel sendiri sudah dijodohkan dengan Zainab, putri dari Cang Rohim. Kisah cinta mereka diwarnai dengan romantika kehidupan masyarakat pinggiran Jakarta yang multi etnis dengan dihadirkannya sosok keluarga si Doel plus Mandra, Bang Jaja, Pak Tile, dan lain-lain (mewakili Betawi) Mas Karyo, Nunung dan Pak Bendot (mewakili Jawa) Mang Eman (Sunda), Ko Ahong (Tionghoa) dan lain sebagainya sehingga sinetron ini menjadi multikultural.

\section{Genre Film}

Jenis Film ceritera yang disukai oleh penontonnya di Indonesia umumnya memiliki genre sebagai berikut:

Romantika/asmara/percintaan; (2) Petualangan; (3) Action; (4) Fiksi Ilmiah; (5) Misteri; dan (6) Komedi (Hidayat, 2016). Terlepas dari masalah genre, sebagai media komunikasi massa, karya film juga bisa ditinjau dari perspektif komunikasi. Menurut tradisi ilmuwan komunikasi, sejak awal ilmu komunikasi ini berkembang, berbagai pesan agar dapat dikomunikasikan dengan efektif, ilmuwan 
komunikasi menyatakan bahwa pesan yang disampaikan itu harus sesuai dengan kerangka referensi (frame of reference) dan bidang pengalaman (field or experience) khalayaknya, jika tidak, sebuah karya film akan sulit untuk dimengerti dan diterima oleh penontonnya. Sejumlah film yang sukses di pasaran sesungguhnya merupakan film-film yang komunikatif yang bisa diterima oleh khalayaknya.

\section{Film sebagai Media Komunikasi Massa}

Selain kesamaan kerangka berfikir dan kerangka pengalaman khalayaknya, menarik pula jika nilai sebuah pesan dalam proses komunikasi massa meminjam juga unsur-unsur news value dalam aktivitas jurnalistik (kendati ada perbedaan mendasar antara jurnalisme sebagai fakta dan film sebagai karya fiksi) keduanya sama-sama ditujukan kepada khalayak komunikasi massa. Elemen news value diadopsi oleh penulis dan disebut sebagai Dramatic Value atau nilai dramatik, diantaranya: (1) Keluarbiasaan; (2) Terkenal; (3) Konflik; (4) Kontras; (5) Proksimiti; (6) Berkaitan dengan seks; dan (7) Human interest (emosi) (Abdullah, 2017).

Berdasarkan hal tersebut di atas, film sebagai produk komunikasi massa harus memiliki unsur-unsur nilai konten sebagai berikut kewajaran ceritera dan penmggarapan, natural, sederhana, mudah dicerna, Berbagai Komponen komunikasi massa tersebut diramu lagi untuk menghasilkan sebuah karya seni sinematografi dengan memperhatikan dan menggali unsur-unsur berikut ini sehingga selain merupakan produk komunikasi massa, film juga merupakan karya seni dengan memperhatikan elemen berikut ini sepertii idea/gagasan, estetika, teknologi serta kreativitas (Abdullah, 2017).

\section{METODE PENELITIAN}

Studi tentang sinetron SDAS ini bertujuan untuk mengetahui tentang: (1) Genre Sinetron Si Doel Anak Sekolahan; (2) Nilai Dramatik Sinetron Si Doel Anak Sekolahan; dan (3) Aspek Komunikasi dalam Sinetron Si Doel Anak Sekolahan. Tulisan ini menggali mengapa SDAS begitu disukai oleh khalayak perfilman nasional baik melalui layar kaca maupun melalui layar bioskop ini dengan metode deskriptif, dengan pengumpulan data dilakukan melalui studi literatur dan observasi terhadap sejumlah episode sinetron "Si Doel Anak Sekolahan".

\section{HASIL DAN PEMBAHASAN}

\section{Genre Film}

Menurut Pratista (2018), kelihatannya mudah untuk menentukan sebuah genre film, namun dalam kenyataannya begitu sulit untuk menentukan genre sebuah film karena dipengaruhi oleh banyak hal (Pratista, 2018). Menurutnya klasifikasi film menurut genre hanyalah konvensi umum yang sifatnya dinamis. Karakteristik sebuah genre tidak bisa mengacu pada satu masa tertentu, namun terus berkembang setiap saat. Faktor inilah mengapa studi terhedap genre begitu sulit. 
Dicontohkannya, Film Film James Bond bisa merupakan campuran genre, disitu ada actions, petualangan, fiksi ilmiah, roman bahkan komedi. Begitu pun SDAS, masuk kategori mana karena di situ ada romantika percintaan, komedi, serta budaya.

Dilihat dari topik atau genre film, sinetron SDAS merupakan perpaduan jenis film antara genre roman dengan komedi. Dua jenis film ini termasuk salah satu film yang digemari karena tema percintaan termasuk tema yang abadi dan universal di hampir semua belahan dunia. Dalam SDAS, kisah utama adalah hubungan cinta segi-tiga antara Doel, Sarah dan Zaenab yang begitu pelik dengan melibatkan banyak pihak.

Selain kisah asmara mereka, ada pula kisah cinta lainnya namun balutannya lebih terkesan humor atau komedi, padahal sebetulnya kisah mereka juga cukup memilukan bagi orang lain. Kisah cinta selain Doel, yakni kisah cinta antara Mandra dengan Munaroh yang berujung kemurkaan orangtua Munaroh karena Mandra batal melamar Munaroh, padahal undangan sudah pada hadir di rumah Munaroh.

Pembatalan tersebut juga tidak lepas karena kisah asmara Engkong Tile (Bapaknya Mandra) yang menduda tiba-tiba membelokan tujuan lamaran bukan ke rumah Munawaroh tetapi ke Nyak Rodiah yang dilamarnya, pedahal pihak keluarga Nyak Rodiah belum siap menerima rombongan Engkong. Adegan ini cukup memilukan, khususnya bagi mereka yang bersimpati pada Mandra sekaligus juga membuat penonton tertawa getir.
Kisah cinta lainnya adalah, jatuh cintanya Mas Karyo kepada Atun. Mas Karyo juga dikisahkan bercerai dengan istrinya yang tinggal di Jawa Tengah. Aneka rayuan gombal khas Mas Karyo juga membuat sinetron ini menarik sebagai sinetron yang memiliki genre percintaan.

Selain bernuansa kisah asmara, SDAS juga kental dengan nuansa komedi. Inilah yang memperkuat sinetron ini sehingga memiliki daya tarik tersendiri. Sinetron ini memadukan dua kekuatan seni tradisional yang selalu kental dengan unsur komedi. Kekuatan itu yakni Ketoprak dari Jawa Tengah dan Lenong dari Betawi. Basuki yang memerankan Mas Karyo, Nunung dan Pak Bendot adalah salah satu kekuatan kesenian atau teater rakyat dari Jawa Tengah tersebut yang juga di era 70-80-an kerap tampil di TVRI dengan grup Srimulat-nya. Sedangkan kesenian rakyat Betawi dengan Lenongnya diwakili oleh Mandra, Bang Jaja, Pak Tile, dan lain-lain. Mereka juga kerap tampil di stasiun yang sama, yakni TVRI.

Selain tema roman percintaan dan komedi, sinetron ini juga memiliki sentuhan budaya tradisional Betawi dimana alur ceritera mengangkat tentang budaya masyarakat Betawi yang tidak perlu sekolah tinggi. Pada budaya Betawi setiap orang sudah merasa cukup hanya dengan kepintaran sembahyang dan mengaji sebagai modal hidup, tidak perlu sekolah tinggitinggi. Selain sikap hidup seperti itu, juga digambarkan tentang seni budaya Betawi lewat episode "Atun Terjepit Trombon" (alat musik tiup ukuran jumbo) yang biasa digunakan dalam seni Tanjidor Betawi. 


\section{Nilai Dramatik Sinetron Si Doel Anak}

\section{Sekolahan: Keluarbiasaan}

Keluarbiasaan yang dimiliki sinetron ini adalah keberanian Rano Karno pada pertengahan dekade 90-an yang melabrak "pakem sinetron layak tayang" yang dipegang teguh oleh kebanyakan stasiun TV swasta di masa itu, dimana Rano Karno sebagai sutradara berani mengangkat tema berlatar tradisi budaya dan kisah tentang kaum marjinal pinggiran Jakarta.

Disebut luarbiasa karena saat itu hampir semua sinetron menampilkan tentang kemewahan sehingga SDAS oleh kebanyakan stasiun TV dinilai tidak akan laku dijual ke khalayak TV Indonesia. Sinetron yang dianggap akan laku yaitu sinetron tentang orang-orang yang mobilnya mengkilap, tinggal di rumah mewah di Jakarta, kalau makan selalu di meja makan dengan menu yang segala ada, pemerannya berangkat kerja selalu berdasi sambil membawa tas jinjing.

Dalam konteks ceritera pada SDAS, luarbiasa ini bukan berarti harus menggambarkan sesuatu yang luarbiasa dengan gegap gempita atau suasana bencana, peperangan yang kolosal, tetapi sestau yang di luar kebiasaan dalam konteks sosiologis. Saat itu dalam semua sinetron di televisi swasta peran orang kecil selalu digambarkan hanya sebagai pembantu rumah tangga, sopir, satpam, tukang ojek, pedagang keliling, atau hansip. Mereka hanyalah pelengkap tidak diangkat sebagai pemeran utama. Pola ceritera dan pemeranan seperti ini sudah menghipnotis pengelola stasiun TV dimana seolah-olah jika membuat sinetron dengan tema yang kontras dari semua itu hanyalah buang-buang duit karena dinilai tidak akan ada orang yang akan menonton. Itu sebabnya empat episode pertama sinetron SDAS ke-1 sempat ditolak oleh sebuah stasiun TV swasta ternama, dan SDAS pun akhirnya hanya diputar di stasiun lain yang ternyata respons penonton sangat luar biasa sehingga SDAS II bisa diterima oleh stasiun yang awalnya menolak.

\section{Nilai Dramatik Sinetron Si Doel Anak}

\section{Sekolahan: Terkenal}

Keterkenalan sosok pendukung atau pemain film memiliki nilai dramatik yang tinggi pada sebuah produksi film sebab bintang terkenal memiliki daya tarik bagi penontonnya. Pada era 80 hingga pertengahan 90-an, Rano Karno termasuk bintang pujaan. Rano Karno termasuk aktor yang bersih dari gosip selain dinilai sebagai artis bersahaja. Rano Karno juga saat itu merupakan aktor ganteng pujaan. Rano Karno juga dikenal sebagai penyanyi, dia memiliki sejumlah album rekaman.

Selain Rano Karno, sosok Benyamin Sueb dan Aminah Cendrakasih juga merupakan aktor senior yang sangat terkenal. Benyamin S merupakan artis serba bisa. Dia dikenal sebagai bintang komedi serta penyanyi gambang kromong yang popular dengan lagu-lagu kocak nan jenaka. Lagu-lagunya selalu hit dan diputar di banyak stasiun radio di jamannya. Basuki (pemeran Mas Karyo) dan Nunung sebelumnya 
juga sudah dikenal oleh penggemar kelompok komedi Srimulat yang kerap tampil di TVRI, dan Mandra dan Pak Tile sebagai bintang Topeng Betawi yang juga kerap tampil di stasiun TV yang sama. Cornelia Agatha saat itu merupakan bintang muda yang juga sudah mulai dikenal di blantika film Indonesia kendati namanya belum terlalu menonjol. Sosok artisartis ini turut memperkuat posisi SDAS sebagai sinetron yang memiliki nilai dramatik tersendiri.

\section{Nilai Dramatik Sinetron Si Doel Anak}

\section{Sekolahan: Konflik}

Konflik merupakan salah satu elemen dalam sebuah ceritera film, dan SDAS pun menampilkan konflik, khususnya konflik batin, yang dialami oleh sejumlah pemerannya. Babeh Sabeni (Benyamin S), Enyak dan juga Doel sendiri memiliki konflik dimana sebagai insinyur lulusan universitas tetapi terus menerus menganggur padahal untuk menyekolahkan $\mathrm{Si}$ Doel hingga universitas Babe sudah habishabisan menjual segala hartanya.

Doel juga harus berkonflik dengan para saingan asmaranya. Misalnya dengan Roy (yang juga menaksir Sarah), dengan Enyak-nya Zaenab yang materialistis serta sejumlah kisah konflik lainnya yang dikemas menjadi tontonan mengharukan sekaligus konflik itu dibalut dengan bungkus komedi khususnya yang melibatkan Mandra yang terkesan selalu ditindas oleh Babehnya sendiri (Pak Tile), oleh kakak iparnya (Bang Sabeni), serta oleh lainnya. Uniknya penindasan terhadap Mandra ini yang muncul di benak penonton adalah suasana humor yang menyegarkan. Sosok Mandra ini pun ikut mendongkrak popularitas sinetron ini.

\section{Nilai Dramatik Sinetron Si Doel Anak Sekolahan: Kontras}

Kekontrasan dalam produk atau konten komunikasi massa merupakan salah satu daya tarik. Yang dimaksud dengan kontras disini adalah perbedaan mencolok atau sesuatu yang bertolak belakang kejadian, kondisi atau fenomena yang selama ini ada. Dari sisi produk acara sinetron, SDAS jelas merupakan sinetron yang bertolak belakang dengan sinetron yang saat itu tengah menjadi trend dalam blantika acara televisi swasta.

Dari sisi konten atau isi ceritera juga, SDAS justru memadukan kekontrasan ini menjadi sebuah tontonan segar tanpa ada pretensi untuk saling merendahkan sehingga nyaris tidak pernah ada yang memasalahkan atau yang mengkritik keras sinetron ini. Sinetron ini berhasil memadukan kekontrasan kaya dan miskin, kota dan dusun, gantengburuk, pintar-bloon, moderen-tradisional, berpendidikan tinggi - tidak berpendidikan.

SDAS mengisahkan tentang keluarga Sarah yang kaya dengan keluarga Doel yang sederhana, bapaknya sopir oplet, enyaknya buka warung. Juga menceriterakan tentang kehidupan Jakarta dan mengisahkan tentang kehidupan orang-orang desa seperti Pak Bendot, Mas Karyo dan Nunung yang diceriterakan sebagai orang desa. Ada juga sosok Mang Eman tukang kredit barang asal Tasikmalaya. Begitu keseharian kehidupan keluarga Bang Sabeni ini yang tinggal di sebuah perkampungan Betawi 
yang asri namun dipisahkan oleh tembok perumahan real eastate yang mewah.

Selain itu, Doel yang ganteng, Sarah yang cantik dipadukan dengan Mandra, Atun dan yang lainnya yang jauh dari sosok ganteng atau cantik. Doel, Sarah atau Hans (sepupu Sarah) yang anak kuliahan yang pintar dipadukan dengan Mandra. Kehidupan moderen Jakarta dipadukan dengan sisi tradisional, serta keluarga sederhana tetapi bersekolah tinggi di tengah keluarga yang tidak sekolah. Doel masih tetap setia dengan Mandra yang buta huruf yang tidak bisa membaca surat kiriman Munaroh kekasihnya, bahkan surat putus cinta dari Munaroh pun baru diketahui isinya setelah dibacakan oleh si Doel seminggu kemudian.

\section{Nilai Dramatik Sinetron Si Doel Anak Sekolahan: Proksimiti}

Proksimiti atau kedekatan memiliki daya tarik bagi khalayak komunikasi massa. Kedekatan ini bisa kedekatan dari sisi geografis, psikologis maupun demografis. Karena yang difilmkan dekat secara geografis, maka sebuah karya film bisa menjadi daya tarik tersendiri bagi warga di lingkungan itu. Begitu pun kedekatan psikologis, orang yang memiliki perasaan, sikap, persepsi, pemahaman dan halhal lainnya yang memiliki seseuatu yang berkaitan secara psikologis akan memberikan perhatian yang lebih ketimbang orang yang tidak secara psikologis memiliki kesamaan. Selain itu yang paling umum proksimiti ini adalah dari sisi demografis, jenis kelamin, usia, pendidikan, pekerjaan, suku bangsa, dan lain- lain. Film anak-anak akan disukai oleh anakanak pula, Film tentang profesi tertentu akan lebih mendapat perhatian dari profesi tertentu ketimbang profesi lainnya.

Bagi masyarakat Betawi mungkin karena ada kedekatan geografis sinetron SDAS menjadi amat digemari. Namun SDAS ini digemari oleh penonton yang juga bukan orang Betawi, boleh jadi penonton di luar Betawi karena mereka memiliki kedekatan psikologis yang amat kuat seperti sikap, persepsi, perasaan, motif atau yang lainnya terhadap SDAS atau personal SDAS ini.

\section{Nilai Dramatik Sinetron Si Doel Anak Sekolahan: Seks}

Elemen ini merupakan fitrah manusia dan disukai secara universal, namun karena dibatasi oleh budaya, norma, agama serta tata aturan lainnya, untuk unsur yang satu ini di negara kita menjadi sesuatu yang terbatas. Di negara liberal seperti di sejumlah negara Barat seperti Eropa atau di AS amat sangat berbeda dengan iklim budaya di negara Timur apalagi di Timur Tengah, itu sebabnya film tentang seks di negara barat menjadi komoditas industri yang luarbiasa besar nilai eknomisnya, sebaliknya di negara timur sangat dibatasi bahkan gunting lembaga sensor akan memotongnya. Kendati demikian ketika film Indonesia mengalami kelesuan di era 90-an pernah pula didominasi oleh produksi film-film yang berbau erotis ini dengan sensor yang agak mengendor. 
Nilai Dramatik Sinetron Si Doel Anak

\section{Sekolahan: Berhubungan dengan Emosi}

Konten media massa yang mengandung unsur-unsur emosi atau perasaan biasanya selalu memiliki daya tarik. Misalnya yang menyebabkan orang sedih, tertawa, tersenyum, tertawa, benci, takut, simpati, cinta, marah, dll. Untuk hal ini yang paling kuat pengaruhnya untuk meraup jumlah penonton yang besar adalah unsur humor atau komedi yang bisa membuat orang tertawa. Film komedi jauh lebih disukai ketimbang film yang mengajak orang tertawa. Juga film-film yang membuat orang takut, seperti film horor serta tentang percintaan (roman). Semua ini sebetulnya juga dipengaruhi oleh faktor demografis juga karena efek sebuah proses komunikasi dipengaruhi oleh banyak hal termasuk aspek demografisnya.

SDAS, memiliki nilai emosi yang tinggi, selain ada unsur cinta juga nuansa komedinya juga lumayan kental. Keberadaan Mandra dan Mas Karyo ikut menyemarakan dan gregetan para penontonnya. Banyak otrang yang tertawa oleh tingkah Mandra, sebaliknya banyak juga yang sebal kepada Mas Karyo karena dinilai selalu licik dan berbuat curang serta sok pintar.

\section{Aspek Komunikasi Sinetron Si Doel Anak}

\section{Sekolahan}

Karya Sinematografi selain sebagai karya seni budaya yang mengedepankan nilainilai estetis, juga merupakan media komunikasi massa. Secara historis maupun yuridis, di Indonesia karya film selalu disebutkan sebagai salah satu media komunikasi massa.
Seringkali terjadi di negara kita sebuah karya film yang secara estetika memiliki nilai yang tinggi ternyata kurang diminati karena kurang komunikatif dengan khalayaknya. Sebaliknya banyak karya sinematografi yang komunikatif dengan khalayaknya namun tidak pernah lolos meraih penghargaan dalam aneka festival. Film yang baik adalah film yang memiliki nilai estetis yang tinggi sekaligus juga komunikatif bagi khalayaknya sehingga film tersebut berhasil dari sisi pemasaran.

Popularitas sebuah karya film dari aspek komunikasi tidak lepas dari unsur khalayak sebagai salah satu unsur komunikasi. Tingkat apresiasi terhadap sebuah karya film memang tidak datang begitu saja. Tingkat apresiasi khalayak terhadap film harus terus ditingkatkan dengan kreativitas para kreatornya agar mampu menciptakan karya yang bagus dari dua sisi, sebagai karya seni dan sebagai produk budaya popular yang komunikatif.

Para ilmuwan komunikasi secara klasik meyakini bahwa proses komunikasi yang berhasil adalah proses komunikasi yang mampu menyetarakan kerangka referensi (frame of reference) dan bidang pengalaman (field of experience) khalayaknya. Jika mengabaikan dua hal itu komunikasi akan gagal. Untuk menyamakan dua kerangka tersebut, para komunikolog acapkali menggunakan psikologi komunikasi, sosiologi komunikasi bahkan filsafat komunikasi untuk menyusun sebuah strategi komunikasi massa, termasuk dalam pembuatan film atau sinetron.

Si Doel Anak Sekolahan, meskipun secara langsung mungkin tidak 
menggunakanakan aspek-aspek ilmu komunikasi, tetapi sesungguhnya sudah menerapkan aneka jurus yang sebetulnya adalah merupakan strategi komunikasi. Rano Karno sebagai sutradara sejak awal memiliki feeling bahwa mayoritas khalayak televisi penyuka sinetron itu mayoritas ada di kelas mana. Dia pun berhasil menarik perhatian mayoritas khalayaknya yang secara psikologis dan sosiologis memiliki kedekatan dan kesukaan terhadap apa yang ditampilkan.

Secara sosiologis, mayoritas khalayaknya perfilman kita sulit diajak untuk berfikir mengerutkan dahi sehingga dibuatlah kisah yang mudah dicerna, sederhana, natural dan wajar. Sifat-sifat tersebut ada dalam sinetron SDAS sejak awal. Latar belakang pemain yang banyak berasal dari kelompok teater rakyat seperti ketoprak atau topeng Betawi membuat mereka lebih banyak berimprovisasi dalam dialog sehingga awalnya membuat bingung sutradaranya karena dialog tidak persis sama dengan naskah skenario. Benyamin Sueb sebagai maestro dia mengaku sulit menghapal naskah skenario yang dianggapnya rigid dan tidak komunikatif sehingga dia lebih rileks dan nyaman dengan aneka ceplas-ceplos celotehannya dengan improvisasi spontan. Untungnya sinetron secara teknis tidak terlalu bermasalah karena dialog pemain tidak melalui proses isi suara atau dubbing.

Rano Karno sebagai sutradara juga berhasil mengarahkan para maestro ketoprak atau lenong yang biasanya jika mereka main di panggung atau di televisi acapkali melakukan komedi slapstik, di SDAS berhasil diarahkan dengan sangat wajar sehingga adegan ke adegan mereka tampil wajar dan natural. Barangkali adegan yang tidak wajar yang muncul dalam SDAS adalah adegan Enyak si Doel yang marah karena cemburu kepada Babe yang naksir seorang penumpang opletnya, enyak lantas menggantung opletnya di ke atas pohon. Adegan ini boleh jadi merupakan humor yang berharap orang tertawa terbahak-bahak, namun karena sejak awal SDAS selalu mengedepankan kewajaran dan kenaturalan, adegan ini menjadi adegan yang dinilai tidak wajar karena tidak masuk akal.

Selain kewajaran dan kenaturalan, secara teknis dalam penulisan skenario selalu menampilkan adegan-adegan pendek yang menghindari dialog-dialog panjang, tetapi dibuat pendek-pendek dari satu karakter ke karakter lain yang masing-masing memiliki problema tersendiri yang dibuat menarik (Armantoro \& Paramita, 2013). Sejumlah sinetron yang berhasil meraih simpati khalayak penonton karena adegan-adegan pendeknya di era sekarang diantaranya Tukang Bubur Naik Haji, Tukang Ojek Pengkolan dan Preman Pensiun.

\section{SIMPULAN}

Dilihat dari topik atau genre film, sinetron SDAS merupakan perpaduan jenis film antara genre roman dengan komedi. Dua jenis film ini termasuk salah satu film yang digemari karena tema percintaan termasuk tema yang 
abadi dan universal di hampir semua belahan dunia. Dalam SDAS, kisah utama adalah hubungan cinta segi-tiga antara Doel, Sarah dan Zaenab yang begitu pelik dengan melibatkan banyak pihak. Dari aspek dramatic values yang terdiri dari (1) Keluarbiasaan; (2) Terkenal; (3) Konflik; (4) Kontras; (5) Proksimiti; (6) Berkaitan dengan seks; dan (7) Human interest (emosi), SDAS juga telah merangkum ketujuh aspek tersebut dalam sebuah pengemasan yang apik di dalam konten-kontennya.

Berdasarkan kajian ilmu komunikasi, SDAS sukses karena kisah yang ditampilkan, tokoh yang dimunculkan, setting dan adegan yang dibangun merupakan refleksi dari wajah khalayak televisi Indonesia sendiri. SDAS adalah gambaran masyarakat Indonesia yang sesungguhnya. Keluguan dan kesederhanaan yang ditampilkan tampil dengan natural tidak berlebihan. Dari sudut pandang ilmu komunikasi klasik, SDAS sudah amat sesuai dengan bidang pengalaman dan kerangka referensi dari khalayaknya.

\section{DAFTAR PUSTAKA}

Abdullah, A. (2017). Film sebagai Media Komunikasi Massa. Bandung.

Armantoro, R., \& Paramita, S. (2013). Skenario: Teknik Penulisan Struktur Ceritera Film. Jakarta: FFTV-IKJ Press.

Hidayat, D. (2016). Sinematografi (Sebuah Pengantar). Bandung: Cahaya Media Utama.

Pratista, H. (2018). Memahami Film (2nd ed.). Yogyakarta: Montase Press.

Ulfa, M. (2018). Daftar 5 Film Indonesia Terlaris Sepanjang 2018 - Tirto.ID. Retrieved February 5, 2019, from https://tirto.id/daftar-5-film-indonesiaterlaris-sepanjang-2018-dbKE 